\title{
AN INVESTIGATION OF THE PRACTICE OF EFFECTIVE TEACHING STRATEGIES IN THREE ISLAMIC SENIOR HIGH SCHOOLS IN SOUTH JAKARTA
}

\author{
Lia Aida
}

SMA Islam Al Azhar 8 Summarecon Bekasi

(aida_evolution@rocketmail.com)

Received: $29^{\text {th }}$ March 2015; Revised: $28^{\text {th }}$ April 2015; Accepted: $28^{\text {th }}$ May 2015

\begin{abstract}
Some research has argued that effective teachers significantly influence students' performance. However, becoming effective teachers are not easy because they have to apply some strategies of effective teaching. For that reason, this paper intends to investigate whether teachers from three Islamic Senior High Schools in South Jakarta practice effective teaching strategies. These schools have been considered good due to the high mean score of English subject in Ujian Nasional. The framework of effective teaching follows the model developed by Creemers and Kyriakides, which relate teacher behavior in the classroom and student achievement. The framework consists of orientation, structuring, questioning, teaching modeling, applications, teacher role in making classroom a learning environment, management of time, and classroom assessment.
\end{abstract}

Key words: teaching; effective teaching; effective teaching strategies

\begin{abstract}
ABSTRAK
Banyak penelitian yang menyatakan bahwa guru-guru yang efektif sangat berperan penting dalam perkembangan siswa. Namun, menjadi guru yang efektif tidaklah mudah karena mereka harus menerapkan beberapa strategi pengajaran yang efektif. Oleh karena itu, paper ini bertujuan untuk melihat apakah para guru yang berasal dari tiga Madrasah Aliyah Negeri (MAN) di daerah Jakarta Selatan mempraktekan strategi pengajaran yang efektif. Framework pengajaran yang efektif mengikuti model yang dikembangkan oleh Creemers dan Kyriakides, yang menunjukkan adanya hubungan antara apa yang dilakukan oleh guru dikelas dengan pencapaian siswa. Framework tersebut terdiri dari: orientation, structuring, questioning, teaching modeling, applications, teacher role in making classroom a learning environment, management of time, and classroom assessment.
\end{abstract}

Kata kunci: pengajara; pengajaran yang efektif; strategi pengajaran yang efektif

How to Cite: Aida. L. (2015). An Investigation of the Practice of Effective Teaching Strategies in Three Islamic Senior High Schools in South Jakarta. IJEE (Indonesian Journal Of English Education), 2(1), 58-75. doi:10.15408/ijee.v2i1.2195

Permalink/DOI: http://dx.doi.org/10.15408/ijee.v2i1.2195 


\section{INTRODUCTION}

Nelson Mandela once said that education is the most powerful weapon which you can use to change the world. The important idea is that a country, which has good quality in education can certainly be a developed country, one of which is Finland. Started from an agricultural country, which was not well-known, today Finland moves forward in technological aspect. For instance, the product of Nokia is spread in the world market. The excellence of Nokia which has varied innovation, commercial enterprise, and technological improvement makes this country as a developed country like Germany, Japan, and the United States. Not only is the improvement supported by research and technological industry, but it is also supported by education.

The education in Finland is categorized best because the country produces high quality generations. For example, in 2013, 93\% the citizens in Finland graduated from Senior High School, which was $17.5 \%$ higher than those in the United States of America. Then, more than $66 \%$ students attended the university which has the best quality in Europe. In addition, the international survey of Organization for Economic Cooperation and Development (OECD) in 2012 reports that Finland was included in one of high-performing countries beside China and South Korea. For instance, in 2012, the Program for International Student Assessment (PISA) which stands for testing literacy in three competence fields like mathematics, science, and reading shows that Finland was ranked first out of 65 countries for mathematics and science. Further, it was also ranked first out of 65 countries for reading (Schleicher, 2014).

In short, these evidences prove that students' performance in Finland is very good. Followint the assumption that teachers play significant roles in students' outcome, it is reasonable to assume that teacher quality in Finland is excellent. Unlike Finland, student achievement in Indonesia has been considered low. In 2012, the Program for International Student Assessment (PISA) showed that Indonesia was ranked 64 out of 65 countries for mathematics and science respectively. In addition, it was also ranked 61 out of 65 countries for reading (Schleicher, 2014). The low achievement was likely to be related with the low quality of most teachers. For instance, the Asian Development Bank (ADB) in 2006 reported that more than $90 \%$ teachers in Madrasah taught lessons which were not in their field such as biology, chemistry, English, and math. This fact indicated that Madrasah teachers in Indonesia had 
low quality in teaching because of low competency and qualification.

In line with this, Strong (2007) states that the teachers who teach a subject for which they are not prepared do not provide students' needs as good as certified teachers. In other words, teachers who are not well-qualified in their own fields become ineffective in teaching. Consequently, this problem could lead to low students achievement.

Nevertheless, this does not mean that there are no good schools, which have high students' achievement. Some Islamic Senior High Schools in South Jakarta such as MAN 4 Jakarta, MAN 11 Jakarta and MAN 19 Jakarta are considered good by public. Students' achievement in those schools is categorized high because of high mean scores of Ujian Nasional (UN), especially for English subject. For instance, in 2013, the mean score of English subject at MAN 4 Jakarta for IPA was (7.70), IPS (7.47), and BAHASA (7.14). Referring to this result, it can be assumed that the English teaching process in those schools are effective.

The above explanations emphasize the idea that effective teaching leads to high student achievement. For that reason, creating an effective teaching becomes an important aspect for Indonesia as a developing country to produce future generations who can compete with other people in the world. This study, therefore, is intended to understand whether teachers apply the principles of effective teaching.

In conceptualizing the effective teaching strategies, the researcher used dynamic model developed by Creemers and Kyriakides (2008) because it relates teacher behavior in the classroom and students' achievement. The model refers to eight effectiveness strategies that describe teachers' instructional role. The strategies are orientation, structuring, questioning, teaching modeling, applications, teacher role in making classroom a learning environment, management of time, and classroom assessment.

Firstly, it is necessary to calrify what we understand about teaching before effective teaching is further discussed. Teaching is frequently considered as a simple process for those who master their subjects. However, the idea of teaching is related to a complex process which is fulfilled with varied people in a complicated social institution (Bruce, 1967).

In line with this, Brown (1987, p.44) said that as a complex process, teaching requires teachers not only to deliver the material, but also to guide and facilitate learning, to enable the 
learner to learn, and to set the condition for learning. Indirectly, this process provides teachers to create an academic cooperative environment in the school.

The content of learning may be facts, procedures, skills, ideas and values which are applied in the learning activities. Moreover, the content is useful in some activities such as comprehending the material, providing student needs, and solving the learning problem which are included in the teaching objectives (Brown and Madeline, 2002, p. 2).

In addition, Moore (2012) explains that teaching is an activity, which provides students to maximize their abilities in all aspects of development. In line with this, Gage (1984) states that not only is an art regarded as a component of teaching, but science is also included as the other component. Teaching has a scientific basis, which applications are derived from research. Further, it is called as an art because it depends on teachers' intuition combined with teacher's experiences. Hence, teaching can be viewed as having both artistic and scientific components (Richard, 2007).

In summary, teaching is a complex process, which involves students' diverse ability and backgrounds in terms of linguistic, cultural, racial, and ethnic diversity.
Teaching is also called as an intentional activity concerned with student learning. The remaining question is how do we define effective teaching, which concerns what teachers do in the classroom that leads to better students' performance.

According to Kriyacou (2009, p. 8), effective teaching can be defined as a teaching process that successfully facilitates students' activities of obtaining knowledge and skills designed by the teacher. This is to say that effective teaching concerns the effects of learning activities on students' performance. In other words, effective teaching deals with teacher activities that lead to better students' performance.

Barry (2010) argues that these activities require a deep inside of subject matter, learning theory of diverse students, designing and teaching strategies, student needs, and evaluation of student outcomes. Further, the activities also involve teachers's competence to reflect, work with team, and keep on establishing professional teaching in order to enhance students' achievement. Further, not only does effective teaching need the teaching strategies, but also require human abilities, instinct, and intelligence to maximize teaching and learning process. 
In summary, effective teaching is defined as a teaching process that successfully achieves the teaching objectives by producing autonomous learners and high student outcomes. In this case, some studies have identified teacher behaviours that facilitate better students' outcome. The findings of these studies have similar ideas concerning what effective teachers do in their classroom. Daniel Muijs and David Reynold (2001, p. 30 - 32), for instance, describe some aspects of effective instructions.

The first is clearly structured lessons. Effective teachers develop lesson that have a clear structure, so pupils can easily understand the content of the lesson and how it relates to what they already know. The second is clearly structured presentations. In this case, effective teachers present materials in small parts according to the pupils' level, which are then practiced before going on to the next step. The next step is pacing, in which basic skills are paced in such a way that during weekly or monthly reviews pupils are able to respond correctly in $90-95$ per cent of cases.

The fourth is modeling, which is a useful procedure to follow when teaching certain topics. Modeling means demonstrating a procedure to learners so that they could learn. The fifth is the use of conceptual mapping, which is a framework that can be presented to pupils before the topic of the lesson is presented. The last is interactive questioning. Effective teachers lead the discussion in the classroom through interactive questioning.

In line with the above elemenets, another expert, Westwood (1996) adds that there are some selected forms of effective teaching. They include presentation and explanation, in which effective teaching requires clarity in presentation and explanation. Effective teaching also involves careful attention to classroom questioning. In addition, effective instruction must include a focus on teaching students efficient ways of approach in the tasks they are set and the provision of adaptive instruction in order to adjust different characteristics and needs of individual students.

Furthermore, Creemers and Kyriakides (2008, p. 104 - 117) develop dynamic model, which comprehensively include various teacher behaviors in the classroom that have been proved to influence students' outcome. The model refers to eight effectiveness strategies that describe teachers' instructional role.

The first is orientation. It refers to the teacher behaviors in providing the 
objectives for which a specific task, lesson, or series of lessons takes place. Orientation also deals eith teacher attempts to challenge students to identify during the lesson the reason why a particular activity takes place. The second is structuring, which emphasize teachers' explanation on the series of activities during the lesson and arranging those activities from easier to more difficult ones.

The third is questioning. Effective teachers formulates both easy and difficult questions and raise them accordingly. The easy or narrow questions usually ask for only factual recall or specific correct answer, whereas difficult or broad questions seldom can be answered with a single word. Moreover, broad questions do not have one correct answer and call on students to reach beyond simple memory. Broad questions prompt students to use the thinking process in formulating answers. Concerning questioning technique, Moore (2012) proposes three types of questions. They are focusing questions, prompting questions, and probing questions. Focusing questions could be factual, empirical, productive, or evaluative, and are used to direct student attention and determine what has been learned by students. Prompting questions use clues that help students answer questions or correct initially inaccurate responses. Probing questions aim at correcting, improving, or expanding a student's initial response. They compel the students to think more thoroughly about the initial response. Probing questions can be used for correcting an initial response, eliciting clarification, developing critical awareness, or refocusing a response. Lastly, when raising questions, it is very important that teachers wait enogh time in order to give students sufficient time to prepare their answers.

The fourth is teaching modeling. This term refers to an orientation toward what students should learn through specific teaching procedures and structures (Arends, 2007). Effective teachers may either present a strategy with clarity or invite students to explain how they solve a problem and subsequently use that information for promoting the idea of modeling. The provision of strategy is important so that students can use the strategy to learn outside the classroom.

This modelling should be completed with application, which refers to learning activities or exercises that effective teachers design to facilitate students' learning. The exercises could refer to some parts of the lesson, to the whole lesson, or even to a series of lessons. In this stage, students are expected to perform. 
The sixth is teacher role in making classroom a learning environment. Effective teachers manages the classroom in such a way that enable different groups of students involved in the classroom interactions. In the dynamic model, five elements of the classroom as a learning environment are taken into account i.e. teacher-student interaction, studentstudent interaction, students' treatment by the teacher, competition between students, and classroom disorder.

The seventh is management of time, which is one of the most important indicators of a teacher's ability to manage the classroom in an effective way. Effective teachers organize and manage the classroom environment as an efficient learning environment and thereby to maximize engagement rates. The last one is classroom assessment, which is seen as an integral part of teaching. Formative assessment, especially, is one of the most important factors associated with effectiveness at all levels, especially at the classroom level.

In this paper, the eight factors explained in the dynamic model is used as a reference in conceptualizing effective teaching. This is because those factors have been previously found to be related to students' outcome. In addition, the model is comprehensive because the factors cover what effective teachers do from the beginning until the end of the classroom session.

In short, this study attempts to investigate whether teachers apply these eight classroom factors of the dynamic model in their teaching practices. The result of the study is expected tp be useful not only for the researcher but also for teachers and other parties. For teachers, the findings of this study could provide important information on what they should do in order to effective teachers. For other parties especially policy makers, the findings could serve as a fundamental basis to develop teacher development program concerning what teachers should focus if they have to improve their quality.

\section{METHOD}

In this study, the researcher used two instruments to gather the data of teaching and lerning process, which were observation sheet and questionnaires. All components of the eight effective teaching principles of the dynamic model were included in both instruments. Five scales were designed in the two instruments to indicate the quality of each observed activity, in which 1 is minimum and 5 is maximum. The questionnaire were given to teachers and students to gather 
their opinion on teaching learning activities whereas an independent observer did the observation.

The sample of this study was ten English teachers at the first and the second grade of three Islamic Senior High Schools in South Jakarta. The sample was chosen by using proportional stratified sampling. The researcher took 6 out of 8 English teachers in MAN 4 Jakarta, 3 out of 5 English teachers in MAN 11 Jakarta, and 1 out of 3 English teachers. So, there were ten English teachers, four males and six females. Concerning the students, there were 243 students who participated in the study.

\section{FINDINGS AND DISCUSSION}

In measuring the practice of effective teaching, the researcher used the data reported by the observer, teachers and students. The total score of effective teaching was gained by summing up the scores of all items divided by the number of the items. In addition, the mean score of each classroom factors of the dynamic model is also presented. This analysis was conducted to understand the teachers' practice of the effective teaching strategies in general and also in each factor. The results are presented in table 1.

Table 1. The Measurement of Teaching Effectiveness (TE)

\begin{tabular}{|c|c|c|c|c|c|c|c|c|c|}
\hline Data & Ori & Stru & Ques & Mode & App & CLE & Time & Ass & ET \\
\hline \multicolumn{10}{|l|}{ Teacher } \\
\hline $\begin{array}{c}\text { Questionnaires } \\
\text { Student }\end{array}$ & 3.63 & 3.60 & 3.44 & 3.43 & 3.70 & 4.10 & 3.70 & 4.04 & 3.70 \\
\hline $\begin{array}{c}\text { Questionnaires } \\
\text { Observation }\end{array}$ & 2.96 & 3.02 & 3.21 & 2.68 & 3.03 & 3.19 & 3.15 & 3.25 & 3.06 \\
\hline Sheets & 2.40 & 1.54 & 2.93 & 2.20 & 2.70 & 2.93 & 2.40 & 3.28 & 2.54 \\
\hline \multicolumn{10}{|l|}{ Notes: } \\
\hline \multicolumn{10}{|c|}{ : Orientation } \\
\hline \multicolumn{10}{|c|}{ : Structuring } \\
\hline \multicolumn{10}{|c|}{ : Questioning } \\
\hline \multicolumn{10}{|c|}{ : Modeling } \\
\hline \multicolumn{10}{|c|}{ : Application } \\
\hline \multicolumn{10}{|c|}{ : Creating Classroom as a Learning Environment } \\
\hline \multicolumn{10}{|c|}{ : Time management } \\
\hline \multicolumn{10}{|c|}{ : The practice of effective teaching } \\
\hline
\end{tabular}


In general, the table explains briefly that there were different perceptions among teachers, students, and the researcher related to the practice of effective teaching. The mean score of effective teaching from the teacher questionnaire shows the highest score compared to those from the students and the observer. The score was 3.63 out five scales. Slightly different from this, the mean score of the students was 3.06. The observer gave the least score, which was only 2.53.These findings mean that teachers themselves viewed that they have used many of the principles of effective teaching while students considered that their teachers did not teach as effective as what the teachers thought. In this case, it is important to note the perception of the observer who could be argued to have better position in understanding the classroom factors of the dynamic model. Because the mean score of the observer reached only 2.53, it means that the teachers did not yet really practice the principle of effective teaching in their teaching and learning process.

The details of the teaching and learning process are explained in the following, which is presented according to the factors of the dynamic model and based on the observation data.
Orientation

Referring to the observer, the mean score of orientation as described in table 1 was 2.53. Therefore, the teachers were not good in practicing the orientation because they did not maximize the applications of the orientation such as reviewing the material, describing the teaching objectives related to daily activities, and challenging the students to identify the reason why a particular topic should be learned. During the observation, there was only one teacher (Ms. F) who reviewed the previous material.

\section{Structuring}

Compared to other factors, structuring was the lowest score, 1.54. This was because most of the teachers did not practice the structuring activities. Almost all teachers did not start their teaching and learning activities with overviewing the objectives of the day lesson not described the content to be covered. The transitions between lesson parts was not given enough attention either. However, there were few teachers who attempted to draw conclusions about the materials that have been taught at the end of the lesson. 


\section{Questioning Technique}

Most teachers practiced questioning in their teaching and learning activities and the mean score reached almost 3. All teachers used familiar English words, asked various questions, gave orderly questions, and provided feedback to the student answers. However, the questions were limited only to questions stated in the textbooks. In other words, the teachers did not really create the questions themselves. In addition, most of the questions required the students to find the answers which were explicitly found in the text. The teachers rarely raised critical questions.

\section{Teaching - modeling}

The data gained in the table mentioned that the teachers were not good in practicing the teachingmodelling. Their mean score was 2.20. They did not provide relevant learning strategies that students can use to learn. The teaching and learning process took place through reading aloud and translating the text and then asnwering questions.

\section{Application Tasks}

Concerning application activities, teachers started to provide exercises during the lesson. They also monitored and supervised students' work during the application stage. On the other hand, the teachers did not give different exercises or theme to different groups of students who had different ability. Furthermore, most teachers did not provide more encouragement to lowachieving students and to praise their success.

The Teacher Role in Making Classroom as a Learning Environment.

In this case, some teachers practiced some activities that can create classroom as a learning environment. For instance they invited the students to respect and to use the school rules and create a businesslike and supportive environment for learning. However, it was quite obvious that some students in several classes were not on tasks and busy with their own activities.

\section{Management of Time}

Table 1 informs us that teachers were not good in managing their time. Some of the time was not spent on teaching and learning activities. Some of the teachers were not successful in finishing all ctivities. In addition, the teachers did not invite the students to finish the learning tasks on time by including time allotment in every student activities. 


\section{Classroom Assessment}

Compared to other factors, classroom assessment was the highest score. This findings mean that teachers were good enough in practicing the classroom assessment. It was obvious during the observation that nearly all teachers attempted to ensure that students understood the lesson by raising some questions. However, the method of conducting assessment was imited to raising questions, which was often conducted at the end of the lesson.

\section{CONCLUSION AND SUGGESTION}

Based on the findings of the study, it was concluded that the teachers have started to practice the strategies of effective teaching at their regular teaching practices. However, this does not mean that it is not necessary for teachers to improve. Moreover, teachers still have a lot of weaknesses in many factors of the dynamic model.

Related to the practice of the orientation, there were three suggestions given to the teachers. First, the teachers should review the material in order to create long-term memory for the students. It is argued to be also effective to examine students' comprehension related to the previous material. Second, it is important for teachers to explain the aim of the lesson by connecting the lesson to the daily activities. This is important to make the tasks meaningful for the students. By explaining the importance of the lesson, it is expected to provide the students opportunities not only to participate actively in the classroom, but also to enhance their critical thinking.

With respect to the practice of the structuring, several suggestions are offered. First, the teachers should begin the class with overviews of the objectives so that students understand what they should achieve at the end of the lesson. Second, through outlining the content and signaling transitions between lesson parts, it would help both the teachers and the students to manage the teaching and learning process easily. Third, the teachers should call attention to main ideas in order to achieve the key concepts of the lesson. Finally, the teachers should give a conclusion at the end of the lesson in order to facilitate the students in memorizing the information that have been discussed.

In terms of questioning technique, there were two suggestions. First, teachers are expected to ask questions at different stages from the beginning and during the lesson as well as at the end of the lesson. It would be useful to check students' understanding and to 
evaluate students' comprehension. In addition, there should be variation of questions concerning the difficulty level. Teachers should also create questions that promote students' critical thinking.

Concerning modeling, there were two suggestions which should be noticed by the teachers. First, the teachers should use one or more strategies to enhance student's skills in solving their learning problems. Further, the teachers should provide the opportunities for the students to use or develop more than one strategy to solve specific problems, or types of problems. Furthermore, they should emphasize on using multiple strategies for a group of students. If possible, teachers should also invite the students to tell how they themselves deal with the problems.

Related to the provision of application tasks, there were three suggestions which should be developed by the teachers. First, the teachers should design relevant tasks in accordance to the goals. Second, the teachers should supervise and provide corrective feedback during the application activities in order to promote better students' performance. The last one, the teachers should pay attention more frequently to lowachieving students and praise their success so that they are eager to compete with other students.

With regards to teachers' role in making classroom as a learning environment, this study proposes two suggestions. First, the teachers should facilitate the establishment of agreement in the classroom to create a learning environment in the classroom. Second, the teachers should use different strategies in order to keep different groups of students involved in the classroom interactions, which promotes student learning. In this case, teachers should also look at the time management, in which they are expected to arrange time allocation for every part of lesson.

Related to the practice of assessment, firstly, the teachers should provide different ways to make sure that students understand the lesson. In addition to questioning, teachers can also ask students to summarize what students learn during the lesson. Second, the teachers use the data they collected from assessment to improve their teaching and learning activities. In addition, from assessment, teachers should be able to identify which topics should be retaught and which groups of students should be provided more attention and assistant. 


\section{REFERENCES}

Arends, Richard I. (2007). Learning to Teach, New York: McGraw-Hill.

Asian Development Bank. (2006). Indonesia: Madrasah education development project, Project Number: 37475-01, Jakarta: SMEC International Pty Ltd.

Barry, Robert A. (2010). Teaching Effectiveness and Why It Matters, Oregon: Marylhurst University.

Bergemann, Arthea J.S., et al. (1998). In The Classroom, Boston: The McGraw-Hill Companies.

Bill \& Mellinda Foundation. (2010). "Empowering Effective Teachers", www.gatesfoundation.org.

Brown, George., and Atkins, Madeleine. (2002). Effective Teaching in Higher Education, London: Taylor \& Francis e-Library.

Brown, H. Douglas. (1987). Principles of Language Learning and Teaching Classroom, New York: Oxford University Press.

Coe, Robert., et al. (2014). What Makes Great Teaching?, Durham University: The Sutton Trust, October.
Creemers, Bert P.M., and Kyriakides, Leonidas. (2008). The Dynamics of Educational Effectiveness, New York: Routledge.

Dunne, Richard., and Wragg, Ted. (2005). Effective Teaching, New York: Taylor \& Francis eLibrary.

Flick, Uwe. (2011). Introducing Research Methodology, London: SAGE.

Gage, Nathaniel. (1984). an Unpdate of the Scientific Basis of the Art of Teaching, Palo Alto, CA: Stanford University.

Gurney, Philip. (2007). Five Factors for Effective Teaching, New Zealand Journal of Teachers' Work.

Hammond, Linda D. (2010). "Recognizing and Developing Effective Teaching", www.aacte.org.

Houser, Rick. (2009). Counseling and Educational Research, Michigan: SAGE Publications, Inc.

Hughes, Arthur. (2003). Testing for Language Teachers, New York: Cambridge University Press.

Johnson, Andrew P. (2008). A Short Guide to Action Research, Boston: Pearson Education, Inc. 
Joyce, Bruce R., and Harootunian Berj (1967). the Structure of Teaching, Chicago: Science Research Associates.

Karimi, Reza. (2011). et al., Integrative Student Learning: An Effective Team Learning Activity in a Learner-Centered Paradigm, 2, http://z.umn.edu/INNOVATI ONS.

Ko, James. (2013). “Effective Teaching: A Review of Research and Evidence", www.cfbt.com,.

Kumar, Ranjit. (2012). Research Methodology, Singapore: SAGE Publication.

Kyriacou, Chirs. (2009). Effective Teaching in Schools: Theory and Practice, Celtenham: Stanley Thornes.

Leedy, Paul D., and Ormrod, Jeanne Ellis. (2014). Practical Research: Planning and Design, London: Pearson Education Limited.

Moore, Keeneth D. (2012). Effective Instructional Strategies, London: SAGE Publications, Inc.

Reynolds, Daniel., and David. (2001). Effective Teaching, London: SAGE.

Ritchie, Jane., and Lewis, Jane. (2003). Qualitative Research Practice, London: SAGE Publication.
Schleicher, Andreas. (2014). "PISA 2012 Results in Focus", www.oecd.org/ pisa..

Stronge, James H. (2007). Qualities of Teachers, Alexandria: Association for Supervision and Curriculum Development ASCD.

Sukadi. (2003). “Efektivitas Pengajaran Dalam Mencapai Kompetensi Siswa Sekolah Menengah Kejuruan", Tesis pada Magister Pendidikan (S2) PPs UNY Prodi PTK.

The Kentucky Departement of Education. (2013).

"Characteristics of Highly Effective Teaching and Learning (CHETL)", http://education.ky.

UIN Syarif Hidayatullah Jakarta. (2011). Pedoman Penulisan Skripsi, Jakarta: Fakultas Ilmu Tarbiyah dan Keguruan.

Westwood, Peter. (1996). Effective Teaching, Australian Journal of Teacher Education, 27.

Yusup, Muhammad., "Strategi Efektif embelajaran Fisika: Ajaran Konsep", Skripsi pada Program Studi Pendidikan Fisika FKIP Universitas Sriwijara.

SAINS Indonesia.(2014). "Budaya Inovasi di Finlandia Patut Ditiru", www.sainsindonesia.co.id. 